\title{
ESTIMATION OF SOME HEAVY METALS CONCENTRATION IN WATER SUPPLY OF DAIRY FARM AND RAW COW'S MILK SOLD IN ASSIUT CITY, EGYPT
}

\author{
YASSER S. WAFY \\ Fellow, Assiut University Hospitals Egypt
}

Received: 27 June 2019; Accepted: 22 July 2019

\begin{abstract}
A total of 120 random samples of dairy water supply, raw cow's milk from different, dairy farms, dairy shops and street vendors (30 samples each) Assiut, Egypt during the period from April 2018 to march 2019 to estimate concentration of Lead, cadmium, manganese and Mercury in water supply of dairy farm and dairy farms, dairy shops and street vendors raw milk samples in Assiut governorate, Egypt. Statistical analytical results of heavy metals mean values (ppm) in dairy farm water supply were $0.192 \pm 0.006,0.0005 \pm 0.0001,0.950 \pm 0.0034$ and $0.648 \pm 0.002$ respectively. While in in dairy farm cow's milk they were $0.084 \pm 0.026,0.032 \pm 0.067,0.830 \pm$ 0.002 and $3.523 \pm 0.002(\mathrm{ppm})$ respectively. But in in dairy shop cow's milk were with means $0.217 \pm 0.045$, $0.053 \pm 0.067,0.900 \pm 0.002$ and $4.200 \pm 0.038$, respectively. The street vendors cow's milk the mean values were found to be $0.289 \pm 0.067,0.064 \pm 0.045,0.954 \pm 0.056$ and $4.769 \pm 0.052$ respectively. All results of heavy metals were in concentration higher than Maximum permissible limits. The health importance of heavy metals and methods of control are discussed.
\end{abstract}

Key words: heavy metals, water supply, dairy farm, raw cow's milk, Assiut, Egypt.

\section{INTRODUCTION}

Milk considered as one of the most important natural food for human at all stages of life. So a greater deal of efforts have been made to produce clean milk and milk products to become save for use and protect it from pollution by many materials as heavy metals. The most important widely distributed heavy metals of toxicological concern are lead $(\mathrm{Pb})$, cadmium $(\mathrm{Cd})$, mercury $(\mathrm{Hg})$ and manganese (Kabzinski, 1998). They are widely distributed in air, water from heavy industries, drainage, fertilizers, sludge applied in the fields and stainless steel used in diary equipment (Naresh et al., 1999). They also may be a pollutant from the use of agricultural pesticides and related chemicals, unhygienic weed out wastes and diffusion of sewage quagmire (Tona et al., 2013). Also, they often deposited in lakes and streams from the air and considered as a main source of water pollution that may be utilized by dairy animals (Enb et al., 2009).

Drinking of polluted water by toxic heavy metals have been responsible for health problems in dairy farms (Mohod and Dhote, 2013). However, water used in the dairy farms for drinking of livestock may be transmitted to dairy animals and appear in a high level in their milk.

Corresponding author: Dr. YASSER, S., WAFY

E-mail address: Yasserwafy2014@yahoo.com

Present address: Fellow, Assiut University Hospitals Egypt
Milk polluted with heavy metals is considered a vehicle for transmission of illness among consumers, especially in developing countries where food hygiene is still under-way due to lack of food hygienists, modern diagnostic methods, beside some environmental conditions and financial difficulties (ELAtrash and Atoweir, 2014). They are able to accumulate in the living tissues and organs as kidney and liver leading to kidney damage and liver cirrhosis (Coggiano et al., 2005) and may be cause toxicity in man and animals due to their cumulative nature resulting in cancer, renal failure, human hypertension, neuropathy of both central and peripheral nervous system, gastroenteritis, diabetes mellitus, anemia and ostiomalacia (Malhat et al., 2012).

This work was planned to estimate concentration of Lead, cadmium ,manganese and Mercury in water supply of dairy farm and dairy farms, dairy shops and street vendors raw milk samples sold in Assiut governorate, Egypt.

\section{MATERIALS AND METHODS}

Collection and handling of the samples:

A total of 120 random samples of dairy water supply, raw cow's milk from different, dairy farms and dairy shops and street vendors (30 samples each) Assiut, Egypt during the period from April 2018 to march 2019 were collected in a clean, dry and sterile containers, and transferred to the laboratory with a 
minimum of delay, whereas they directly examined or held in the refrigerator until time of examination.

\section{Preparation, digestion and estimation of samples:}

Water digestion (Chau et al., 1979):

Five milliliter of each sample was transferred to a digestion flask where it was treated with $5 \mathrm{ml}$ of nitric and perchloric acids mixture (HNO3: HCLO4 = 4:1 $\mathrm{v} / \mathrm{v})$. The samples were left to be stand for the cold digestion overnight, and then were heated on a hot plate (model 1030-RuMO 100) at $70^{\circ} \mathrm{C}$ till disappearance of the brown fumes of $\mathrm{NO} 3$ and the sample become clear. After cooling, each sample was diluted to $25 \mathrm{ml}$ with bi-distilled water and filtered through ashless filter paper (Whatman paper). The digested samples were kept refrigerated in $50 \mathrm{ml}$ propylene bottles till analysis.

\section{Milk digestion (Slavin et al., 1975):}

Milk samples were digesed according to Slavin et al. (1975) with some modification as follow:

From each milk sample, $25 \mathrm{ml}$ was drawn with clean sterile $25 \mathrm{ml}$ glass pipette and placed in clean dried $250 \mathrm{ml}$ Erlenmeyer flask.

Erlenmeyer flasks that contained milk samples were put in hot air oven at $100 \mathrm{C}$ for half an hour and then were left at 50C for 24 hours till evaporation of water from the milk sample occurred .
$25 \mathrm{ml}$ digestion mixture (Equal volumes of concentrated nitric acid and $72 \%$ perchloric acid) were added to each flask, shaked and the acid was allowed to react at room temperature for 24 hours to facilitate the processes of digestion.

After this the flasks were put on hot plate at approximately $100 \mathrm{C}$, shaked and several milliliters of concentrated nitric acid were added in each flask during the process of heating. Heating continued till the sample become colorless (complete digestion of the sample and disappearance of the brown gas (Nitricoxide, NO3) after its evaporation from the flask).

Samples were allowed to cool, filtered with filter paper, flasks then washed out several times with ion free water till the final volume of the digested sample reach $25 \mathrm{ml}$. These samples stored at refrigerator tell their analysis and estimation of Aluminum.

Determination of Lead, Cadmium, Manganese and Mercury in milk samples in ppm were estimated in the digested milk samples by means of, atomic absorption spectrophotometer (Shimadzu Atomic absorption / flame spectrophotometer ModelAA63002P / N204-27600-02AA630-02), Kyoto-Japan. Analysis line wave length, Lamp current, slite width, Brner flam and support gas flow (e / min) for it were Analysis linewave length: nm, Lamp crrent: $\mathrm{mA}$, Slit width: Burner flam: cm air-C2H2, Spport gas flow (e /min.)

\section{RESULTS}

Table 1: Statistical analytical results of heavy metals concentration (ppm) in dairy farm water supply.

\begin{tabular}{|c|c|c|c|c|c|c|c|}
\hline \multirow{2}{*}{$\begin{array}{l}\text { Heavy } \\
\text { metals }\end{array}$} & \multirow{2}{*}{$\begin{array}{l}\text { No. of exam. } \\
\text { samples }\end{array}$} & \multicolumn{5}{|c|}{ Positive samples } & \multirow{2}{*}{$\begin{array}{c}\text { Maximum permissible } \\
\text { limits according to } \\
\text { WHO, } 2011(\mathrm{ppm})\end{array}$} \\
\hline & & No. & $\%$ & Minimum & Maximum & $\begin{array}{l}\text { Mean } \pm \\
\text { SE }\end{array}$ & \\
\hline Lead & 30 & 22 & 73.33 & 0.156 & 0.235 & $\begin{array}{c}0.192 \pm \\
0.006 \\
\end{array}$ & 0.01 \\
\hline Cadmium & 30 & 17 & 56.66 & 0.0004 & 0.0007 & $\begin{array}{c}0.0005 \pm \\
0.0001 \\
\end{array}$ & 0.003 \\
\hline Manganese & 30 & 12 & 40 & 0.460 & 1.380 & $\begin{array}{l}0.950 \pm \\
0.0034\end{array}$ & 0.1 \\
\hline Mercury & 30 & 7 & 23.33 & 0.002 & 0.780 & $\begin{array}{c}0.648 \pm \\
0.002\end{array}$ & 0.5 \\
\hline
\end{tabular}

Table 2: Statistical analytical results of heavy metals concentration (ppm) in dairy farm cow's milk samples.

\begin{tabular}{llcccccc}
\hline \multirow{2}{*}{$\begin{array}{l}\text { Heavy } \\
\text { metals }\end{array}$} & $\begin{array}{c}\text { No.of } \\
\text { Lead }\end{array}$ & exam.samples & No. & Positive samples & Minimum & Maximum & Mean \pm SE \\
\cline { 3 - 7 } & 30 & 19 & 63.33 & 0.019 & 0.212 & $0.084 \pm 0.026$ \\
\hline Cadmium & 30 & 11 & 36.66 & 0.003 & 0.038 & $0.032 \pm 0.067$ \\
\hline Manganese & 30 & 8 & 26.66 & 0.40 & 1.300 & $0.830 \pm 0.002$ \\
\hline Mercury & 30 & 5 & 16.66 & 0.001 & 5.400 & $3.523 \pm 0.002$ \\
\hline
\end{tabular}


Table 3: Statistical analytical results of heavy metals concentration (ppm) in dairy shop milk in raw cow's milk samples.

\begin{tabular}{ccccccc}
\hline \multirow{2}{*}{$\begin{array}{c}\text { Heavy } \\
\text { metals }\end{array}$} & $\begin{array}{c}\text { No. of exam. } \\
\text { samples }\end{array}$ & No. & $\%$ & Minimum & Maximum & Mean \pm SE \\
\cline { 3 - 7 } Lead & 30 & 22 & 73.33 & 0.082 & 0.496 & $0.217 \pm 0.045$ \\
\hline Cadmium & 30 & 14 & 46.66 & 0.008 & 0.085 & $0.053 \pm 0.067$ \\
\hline Manganese & 30 & 8 & 26.66 & 0.540 & 1.380 & $0.900 \pm 0.002$ \\
\hline Mercury & 30 & 6 & 30 & 0.012 & 5.200 & $4.200 \pm 0.038$ \\
\hline
\end{tabular}

Table 4: Statistical analytical results of heavy metals concentration (ppm) in street vendors milk in raw cow's milk samples.

\begin{tabular}{ccccccc}
\hline \multirow{2}{*}{$\begin{array}{c}\text { Heavy } \\
\text { metals }\end{array}$} & $\begin{array}{c}\text { No. of exam. } \\
\text { samples }\end{array}$ & No. & \%ositive samples \\
\cline { 3 - 7 } Lead & 30 & 23 & 76.66 & 0.089 & 0.568 & $0.289 \pm 0.067$ \\
\hline Cadmium & 30 & 16 & 53.33 & 0.006 & 0.096 & $0.064 \pm 0.045$ \\
\hline Manganese & 30 & 8 & 26.66 & 0.630 & 1.700 & $0.954 \pm 0.056$ \\
\hline Mercury & 30 & 8 & 20 & 0.018 & 5.986 & $4.769 \pm 0.052$ \\
\hline
\end{tabular}

Table 5: The relationship between international permissible limits of heavy metals (ppm) and mean finding in dairy farm water supply, dairy farm's, dairy shop's and street vendor 's cow's milk.

\begin{tabular}{ccccc}
\hline heavy metals & $\begin{array}{c}\text { Mean } \pm \text { SE } \\
\text { dairy shop }\end{array}$ & $\begin{array}{c}\text { Mean } \pm \text { SE } \\
\text { street vendors }\end{array}$ & $\begin{array}{c}\text { Mean } \pm \text { SE } \\
\text { dairy farm }\end{array}$ & $\begin{array}{c}\text { Maximum permissible limits } \\
\text { According to IDF Standard } \\
\text { (1979) and Codex (2007) }\end{array}$ \\
\hline Lead & $0.084 \pm 0.026$ & $0.217 \pm 0.045$ & $0.289 \pm 0.067$ & 0.02 \\
\hline Cadmium & $0.032 \pm 0.067$ & $0.053 \pm 0.067$ & $0.064 \pm 0.045$ & 0.0026 \\
\hline Manganese & $0.830 \pm 0.002$ & $0.900 \pm 0.002$ & $0.954 \pm 0.056$ & 0.05 \\
\hline Mercury & $3.523 \pm 0.002$ & $4.200 \pm 0.038$ & $4.769 \pm 0.052$ & 4.0 \\
\hline
\end{tabular}

\section{DISCUSSION}

Polluted drinking water play important roles in transmition of many types of heavy metals to dairy animals and appear in milk causing many problems to the consumers for man and animals may reach to a toxicity level (Jaleel et al., 2001). Lead (Pb), cadmium $(\mathrm{Cd})$, manganese $(\mathrm{Mn})$ and mercury $(\mathrm{Hg})$ are the most distributed heavy metals in water (Kabzinski, 1998).

The summarized results in Tables 1 showed that Statistical analytical results of heavy metals (ppm) in dairy farm water supply were 22(73.33\%), 17 $(56.66 \%), 12(40 \%)$ and $7(23.33 \%)$ of examined samples (30 samples) + ve for Lead, Cadmium, Manganese and Mercury, respectively. The incidence of lead, cadmium, manganese and mercury (ppm) ranged from $0.156,0.0004,0.460$ and 0.002 to 0.235 , $0.0007,1.380$ and 0.780 with mean ranges $0.192 \pm$ $0.006,0.0005 \pm 0.073,0.950 \pm 0.0034$ and $0.648 \pm$ 0.002 , respectively. In the other hand, these results of water samples were significantly higher in lead,
Manganese and Mercury than Maximum permissible limits according to WHO, 2011 (ppm) but cadmium appear in save percentage which low the Maximum permissible limits according to WHO, 2011 (ppm) .

These results agree with that obtained by Jaleel $e t$ al. (2001), Nassef et al. (2006); Abdl-khalik et al. (2013); Wongsasuluk et al. (2014); Boateng et al. (2015); Aamer et al. (2016).

The obtained result in Table 2 revealed that Statistical analytical results of heavy metals ( $\mathrm{ppm})$ in dairy farm cow's milk were19 (63.33), 11 (36.66), 8 (26.66) and 5 (16.66) of examined samples + ve for Lead, Cadmium, Manganese and Mercury, respectively. The incidence of lead, cadmium, manganese and mercury (ppm) ranged from $0.019,0.003,0.40$ and 0.001 to $0.212,0.038,1.300$ and 5.400 with mean ranges $0.084 \pm 0.026,0.032 \pm 0.067,0.830 \pm 0.002$ and $3.523 \pm 0.002$ respectively.

The summarized results in Table 3 Pointed out Statistical analytical results of heavy metals (ppm) in 
dairy shop cow's milk were 22 (73.33 ), 14 (46.66), 8 (26.66) and 6 (30) of examined samples (30 samples) + ve for Lead, Cadmium, Manganese and Mercury respectively. And the incidence of lead, cadmium, manganese and mercury ( $\mathrm{ppm}$ ) ranged from 0.082, $0.008,0.540$ and 0.012 to, $0.496,0.085,1.380$ and 5.200 with mean ranges $0.217 \pm 0.045,0.053 \pm 0.067$, $0.900 \pm 0.002$ and $4.200 \pm 0.038$, respectively.

The results of Table 4 revealed that Statistical analytical results of heavy metals (ppm) in street vendors cow's milk were 23 (76.66), 16(53.33), 8 (26.66) and 8 (26.66) of examined samples (30 samples) + ve for Lead, Cadmium, Manganese and Mercury respectively. And the incidence of lead, cadmium, manganese and mercury (ppm) were ranged from, $0.089,0.006,0.630$ and 0.018 to 0.568 , $0.096,1.700$ and 5.986 with a mean range $0.289 \pm$ $0.067,0.064 \pm 0.045,0.954 \pm 0.056$ and $4.769 \pm 0.052$ respectively.

Nearly similar results of lead, Cadmium and Mercury were obtained by Saad et al. (2001); Pavlovic et al. (2004); Gabryszuk et al. (2010); Bilandžić et al. (2011); Malhat et al. (2012); Abdl-khalik et al. (2013); Aamer et al. (2016). Same results were obtained by Haldar et al. (2003); Santos et al. (2015) for Manganese who found Mn in cow's milk with the range of 1.60 to $1.69 \mathrm{ppm}$.

The obtained results Table 5 mentioned that the mean finding of heavy metals in dairy farms, dairy shops and street vendor's cow's milk were significantly higher level of lead, Cadmium ,Manganese and Mercury than the maximum permissible according to IDF Standard (1979) and Codex (2007).

Drinking water supply contain heavy metals concentration higher than Maximum permissible limits according to WHO, (2011) (ppm) mean level of this may be due to contamination from air, water from heavy industries, drainage, fertilizers, sludge applied in the fields and stainless steel used in diary equipment (Naresh et al., 1999). Dairy farm milk contain heavy metals in concentration higher than maximum permissible limits according to IDF Standard (1979) and Codex (2007) where the concentration of heavy metals in market raw milk samples considerably higher than those detected in dairy farm milk. This may be due to the different sources of samples which depend on the surrounding circumstances (Saad et al., 2001; Kodrik et al., 2011).

Polluted Milk with heavy metals is considered a vehicle for transmission of illness among consumers, which accumulate in the living tissues and organs as kidney and liver leading to kidney damage and liver cirrhosis (Coggiano et al., 2005). Resulting in cancer, renal failure, human hypertension, neuropathy of both central and peripheral nervous system, gastroenteritis, diabetes mellitus, anemia and ostiomalacia (Hagag and Fayz, 2012). And may be cause toxicity in man and animals. (Klopov, 1998 and Eife et al., 1999).

\section{CONCLUSION}

At the end of this study we can conclude that Polluted drinking water play important roles in transition of many types of heavy metals as Lead, cadmium, manganese and mercury to dairy animals and appear in milk causing many problems (Jaleel et al., 2001) and there is a significant relationship between heavy metal pollution of milk and those in water samples. This mean that the main source of milk polluted with heavy metals from water contamination.

Water supply must be protected from chemical contaminants, effluents and sewage to assure health safety for human and animals.

Periodical examination of milk for chemical pollution specially heavy metals.

\section{REFERENCES}

Aamer, H.A.; Hassan, M.D. and Kotb, S. (2016): Estimation Of Some Metallic Pollutants In Drinking Water Of Some Poultry Farms At Assiut Governorate. Assiut Vet. Med. J. Vol. 62 No. 149, 1-12.

Abdl-Kalik, A.; Azza, G.M. and Raslan (2013): Estimation of Some Heavy Metals in Cow's Milk In Zagazig Assiut Vet. Med. J. Vol. 59 No. 138- 74: 77.

Bilandžić, N.; Dokić, M.; Sedak, M.; Božica, S.; Varenina, I. and Knežević, Z. (2011): Trace element levels in raw milk from northern and southern regions of Croatia. Food Chemistry; 127(1): 63-66.

Boateng, T.K.; Opoku, F.; Acquaah, S.O. and Akoto, $O$. (2015): Pollution evaluation, sources and risk assessment of heavy metals in hand-dug wells from Ejisu-Juaben Municipality, Ghana. Environ Syst Res (2015) 4: 18

Caggiano, R.; Sabia, S.; D'Emilio, M.; Macchiato, M.; Anastasio, A.; Ragosta, M. and Paino, S. (2005): Metal levels in fodder, milk, dairy products and tissue sampled in farms of Southered Italy. Environmental Research, 99 (1): 48-57.

Chau, Y.K.; Wong, P.T.S. and Bengert, G.A. (1979): Determination of tetra-alkyl-lead compounds in water, sediments, and fish samples. Anal Chem. 51: 186-188.

Codex Alimentarius Commission (2007): Codex standard for food grade salt. CX STAN 1501985, Amend, 3-2007. 1-7. In: World Health Organization/Food and Agriculture Organization of the United Nations, Rome. 
Eife, R.; Weiss, M.; Barros, V.; Sigmund, B.; Goriup, U.; Komb, D.; Wolf, W.; Kittel, J.; Schramel, $P$. and Reister, K. (1999): Chronic poisoning by copper in tap water. Copper intoxication with predominately gastrointestinal symptoms. Eur. J. Med. Res. 4 (6): 219-233.

El-atrash, S. and Atoweir, N. (2014): Determination of lead and cadmium in raw cow's milk by graphite furnace atomic absorption spectroscopy. International Journal of Chemical Sciences, 12(1): 92-100.

Enb, A.; Abou Donia, M.A.; Sbd-Robu, N.S.; Abo Arab, A.K. and El-Semaity (2009): Chemical compotation during processing of milk product. Global Veterinaria, 3: 268-275.

Gabryszuk, M.; Słoniewski, K.; Metera, E. and Sakowski, T. (2010): Content of mineral elements in milk and hair of cows from organic farms. Journal of Elementology. 15(2): 259-267.

Hagag, M.F. and Fayz, S.A.E. (2012): Contamination of cow's milk by heavy metal in Egypt. Bull Environ. Contam. Toxicol., 88 (4): 611-613.

Haldar, S.; Ghosh, T.K. and Pal, N. (2003): Effects of trace elements supplementation in commercially reared dairy Research Journal 22(3): 981-986

IDF Standard. (1979): International Dairy Federation Bulletin, Chemical residues in milk and milk products. I.D.F. Document, 133.

Jaleel, MA.; Noreen, R. and Baseer, A. (2001): Concentration of heavy metals in drinking water of different localities in district east Karachi. J. Ayub Med. Coll Abbottabad. OctDec, 13(4): 12-5.

Kabzinski, A.K. (1998): Application of covalent affinity chromatography with thiol-disulfide interchanges for determination of environmental exposition to heavy metals based on the quantitative determination of Znthionein from physiological human fluids by indirect method on analysis of metal content. Biomed. Chromatogr., 12 (5): 281290.

Kodrik, L.; Wagner, L.; Imre, K. and Husveth, F. (2011): The effect of highway traffico on heavy metals content of cow milk and cheese. Hungarian Journal of Industrial Chemistry Veszprem. 29 (1): 15-19.

Klopov, P.V. (1998): Levels of heavy metals in women residing in the Russian Arctic. Int. J. Circumpolar Health, 57 (1): 582-585.

Malhat, F.; Hagag, M.; Saber, A. and Fayz, A.E. (2012): Contamination of cow's milk by heavy metal in Egypt. Bulletin of environmental contamination and toxicology. 88: 611-613.
Mohod, C.V. and Dhote, J. (2013): Review of heavy metals in drinking water and their effect. International Journal of Innovative Research in Science, Engineering and Technology 2(7): 2992-2996.

Naresh, R.; Dwivedi, K.; Swarup, D. and Dey, S. (1999): Lead and cadmium concentrations in milk and blood of Indian cows with mastitis. Vet. Hum. Toxicol., 41 (6): 392-393.

Nassef, M.; Hannigan, R.; EL Sayed, K.A. and ElTahawy, M.S. (2006): Determination of Some Heavy Metals In the Environment of Sadat Industrial City. Proceedings of the 2nd Environmental Physics Conference, 18-22 Feb. 2006, Alexandria, Egypt.

Pavlovic, I.; Sikiric, M.; Havranek, J.L.; Plavljanic, N. and Brajenovic, N. (2004): Lead and cadmium levels in raw cow's milk from an industrialized Croatian region determined by electro-thermal atomic absorption spectrometry. Czech J. Anim. Sci., 49(4): 164168.

Saad, A.; El-Kosi, O. and Abdel-Hakiem, E. (2001): Surveillance of some heavy metals in raw milk. 1st Cong. of Food Hygiene \& Human Assiut Vet. Med. J. Vol. 59 No. 138 July 2013 78 Health February. Dept. Food Hygiene, Fac. Vet. Med., Assiut University, p. 258-270.

Slavin, S.; Barnett, W.B. and Kahn, H.L. (1975): The Determination of Atomic Absorpation Detection Limits by Direct Measument. Atomic Absorption Newsleter 11: 37-41.

Santos, C.B.G.; Oliveira, A.P.; Martins, D.L.; Oliveira, J.C.; Pedro, F.G.G. and Villa, R.D. (2015): Determination of the concentrations of essential and toxic metals in UHT milk produced in Mato Grosso State, Brazil. International Food.

Sayed, M.M. and Omar, M.H. (2013): 39 Estimation of Some Metallic Pollutants in Drinking Water of Some Poultry Farms At Assiut Governorate. Assiut Vet. Med. J. Vol. 59 No. 139-39: 43.

Tona, G.O.; Adetunji, V.O.; Ameen, S.A. and Ibikunle, A.O. (2013): Evaluation of Lead and Cadmium Heavy Metal Residues in Milk and Milk Products Sold in Ogbomoso, Southwestern Nigeria. Pakistan Journal of Nutrition 12 (2): 168-171.

WHO (World Health Organization) (2011): Guidelines for drinking-water quality, $4^{\text {th }} \mathrm{Ed}$. Switzerland, Geneva

Wongsasuluk, P.; Chotpantarat, S.; Siriwong, W. and Robson, M. (2014): Heavy metal contamination and human health risk assessment in drinking water from shallow groundwater wells in an agricultural area in UbonRatchathani province, Thailand. Environ. Geochem. Health. 36: 169-182. 


\section{تقدير تركيز بعض المعادن الثقيلة في مصادر المياه فى مزارع الألبان وحليب البقر الخام المباع في مدينة أسيوط ، مصر مرارع \\ باسسر وافى}

E-mail: Yasserwafy2014@yahoo.com

Assiut University web-site: $\underline{w w w . a u n . e d u . e g}$

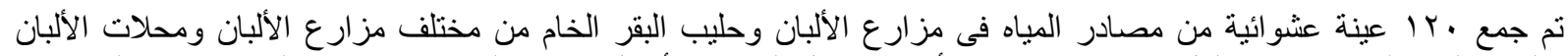

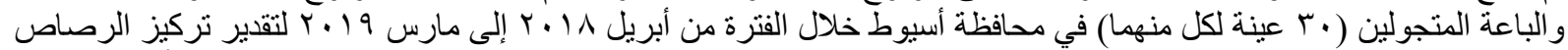

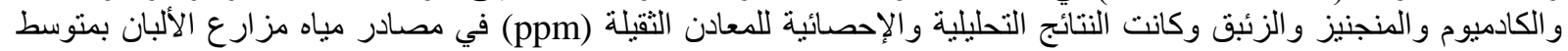
ج • , •

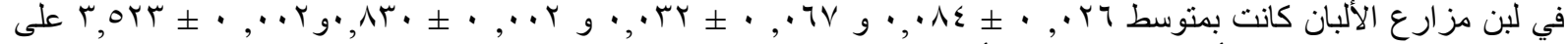

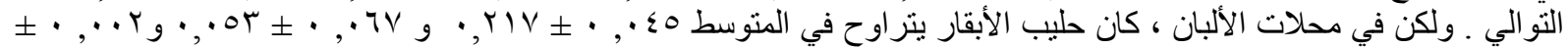

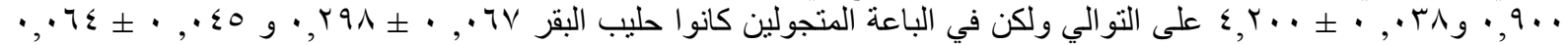

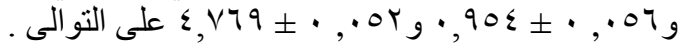

وكانت جميع نتائج المعادن الثقيلة في تركيز أعلى من الحدود القصوى المسموح بها دوليا. وتم مناقتنة الأهمية الصحية للمعادن الثقيلة وطرق التحكم فيها. 